\title{
Primitive melt composition of the Bultfontein Kimberlite (South Africa).
}

\author{
Ashton Soltys ${ }^{1}$, Andrea Giuliani ${ }^{1,2}$, David Phillips ${ }^{1}$ \\ ${ }^{1}$ KiDs (Kimberlites and Diamonds), School of Earth Sciences, The Univeristy of Melbourne, Parkville, 3010 \\ Victoria, Australia \\ soltysa@student.unimelb.edu.au \\ ${ }^{2}$ ARC Centre of Excellence for Core to Crust Fluid Systems and GEMOC, Department of Earth and Planetary \\ Sciences, Macquarie University, North Ryde, 2019 NSW, Australia
}

\section{Introduction}

The compositions of kimberlite melts at depth remain elusive. This can be attributed to the unquantified effects of multiple complex processes (e.g., alteration, assimilation, and incorporation of xenogenic material) which modify kimberlites pre-, syn- and post-emplacement. In turn, our inability to accurately constrain the composition and physical properties of kimberlite melts prevents a comprehensive understanding of their petrogenesis.

\section{Method and Approach}

To improve constraints on the compositions of kimberlite melts, we have adopted a new approach to reconstruct primtive melt compositions, which combines detailed modal analysis, including discerning xenocrystic from magmatic phases, and determination of mineral compositions. The accuracy of this reconstruction process is validated by the similarity between reconstructed and measured whole-rock values. To this reconstructed whole-rock composition we apply a series of corrections and assumptions to account for the effects of post-emplacement alteration (dominantly serpentinisation) as well as the inclusion and assimilation of mantle material. This reconstruction method involves a number of different stages which are outlined below.

Stage 1: Whole-rock reconstruction.

Stage 2: Correction for pseudomorphic serpentinisation of monticellite, assuming a constant volume replacement process occurring in an open system (e.g., Sparks et al. 2009). We model this generation of pseudomorphic serpentine as having a completely deuteric origin because monticellite is enclosed in carbonates with magmatic textures and composition.

Stage 3: Formation of matrix serpentine from deuteric (Model I), external (Models II to IV) or mixed fluids (Model V). In addition to modeling different fluid sources, the replaced phases (Models III to V) vary between models. In Model A serpentine is considered a primary duteric phase (e.g., Mitchell 2013), whereas in Model B matrix serpentine is considered a secondary phase (e.g., Afanasyev et al. 2014). Models $C$ and $D$ involve replacement of various combinations of alkali-carbonate phases based on the suggestions of Kamenetsky et al. (2014). Finnaly, Model E considers serpetine is derived from 30\% duteric and $70 \%$ external fluids, where serpentine replaced carbonates (calcite and dolomite). This is our preferred model, and is based on detailed petrographic observations of sample BK (Giuliani et al., 2016).

Stage 4: Removal of xenocrystic components (i.e., olivine and phlogopite).

Stage 5: Correction for orthopyroxene assimilation, where the amount of orthopyroxene is estimated based on the amount of xenocrystic olivine in sample BK and the ratios of olivine to orthopyroxene in mantle xenoliths from the Kaapvaal craton.

Stage 6: Correction for clinopyroxene and garnet assimilation. The amount of clinopyroxene and garnet is estimated in the same way as orthopyroxene. In light of poor constraints on the extent of assimilation 
of these phases, we model complete $(\mathrm{C})$, and partial (P) assimilation of clinopyroxene and garnet (i.e., $60 \%$ and $40 \%$, respectively - arbitrary values).

\section{Results}

The primitive melt reconstructed at from Model $E$ (our prefered model) contains 22.2 wt.\% $\mathrm{SiO}_{2}, 23.5$ wt. $\% \mathrm{MgO}, 23.8$ wt. $\% \mathrm{CaO}, \sim 1.8$ wt. $\% \mathrm{H}_{2} \mathrm{O}, \sim 12.7$ wt. $\% \mathrm{CO}_{2}, 3.5$ wt. $\% \mathrm{P}_{2} \mathrm{O}_{5}, 1.6$ wt. $\% \mathrm{TiO}_{2}, 1.2$ wt. $\%$ $\mathrm{Al}_{2} \mathrm{O}_{3}$ and 0.8 wt. $\% \mathrm{~K}_{2} \mathrm{O}$, and has a $\mathrm{Mg \#}$ value of 83.2 (see Table 1). When compared with Model A (i.e., all serpetine considered as duteric), Model $E$ contains significantly less $\mathrm{SiO}_{2}$, and $\mathrm{MgO}$, and more $\mathrm{CaO}$ and $\mathrm{CO}_{2}$. This primitive melt composition (Model E) is also poorer in $\mathrm{SiO}_{2}, \mathrm{MgO}$ and $\mathrm{H}_{2} \mathrm{O}$, but enriched in $\mathrm{CaO}$ and $\mathrm{CO}_{2}$ compared with most previous reconstructions of primitive kimberlite melts based on southern African or Canadian samples (Table 1). The reconstructed primtive melt repored here is remarkably similar to the reconstructed primitive melt parental to the Majuagaa kimberlite, Greenland (Neilson and Sand, 2008).

These results suggest primitive kimberlites are transitional silicate-carbonate melts (i.e., melts with 1832 wt. $\% \mathrm{SiO}_{2}+\mathrm{Al}_{2} \mathrm{O}_{3}$ ), which become progressively enriched in $\mathrm{SiO}_{2}, \mathrm{MgO}$ and to a lesser extent $\mathrm{Al}_{2} \mathrm{O}_{3}$ and $\mathrm{Cr}_{2} \mathrm{O}_{3}$ through the assimilation of lithospheric mantle material. Importantly, these results are seemingly not consistent with the suggestion that kimberlites are produced as $\mathrm{SiO}_{2}$-free 'carbonatitic' melts that are converted to kimberlitic compositions by extensive assimilation.

\begin{tabular}{|c|c|c|c|c|c|c|c|c|c|c|c|}
\hline & XRF & Stage 1 & \multicolumn{2}{|c|}{ Stage 6} & \multicolumn{2}{|c|}{ Total change $\$$} & 1 & 2 & 3 & 4 & 5 \\
\hline & & & Model A & Model E & Model A & Model E & & & & & \\
\hline$\overline{\mathrm{SiO}_{2}}$ & 30.66 & 30.83 & 26.02 & 22.18 & -4.81 & -8.65 & 26.50 & 25.60 & 31.79 & 26.70 & 17.47 \\
\hline $\mathrm{TiO}_{2}$ & 1.54 & 1.18 & 1.55 & 1.56 & 0.37 & 0.38 & 2.20 & 3.35 & 0.72 & 1.73 & 4.99 \\
\hline $\mathrm{Al}_{2} \mathrm{O}_{3}$ & 1.83 & 1.32 & 1.19 & 1.18 & -0.13 & -0.14 & 2.20 & 3.31 & 3.08 & 1.57 & 2.27 \\
\hline $\mathrm{Cr}_{2} \mathrm{O}_{3}$ & 0.18 & 0.15 & 0.12 & 0.12 & -0.03 & -0.03 & n.d. & 0.24 & n.d. & 0.36 & 0.28 \\
\hline $\mathrm{FeO}_{\mathrm{t}}$ & 9.35 & 9.23 & 8.97 & 8.44 & -0.26 & -0.79 & 8.00 & 10.30 & 8.28 & 7.58 & 10.61 \\
\hline MnO & 0.18 & 0.11 & 0.10 & 0.09 & -0.01 & -0.02 & n.d. & 0.21 & 0.19 & 0.18 & 0.24 \\
\hline MgO & 31.42 & 31.21 & 25.50 & 23.47 & -5.71 & -7.74 & 26.50 & 27.20 & 30.77 & 28.25 & 23.98 \\
\hline $\mathrm{NiO}$ & & 0.13 & 0.05 & 0.05 & -0.08 & -0.08 & 0.01 & 0.01 & n.d. & n.d. & 0.02 \\
\hline $\mathrm{CaO}$ & 10.93 & 12.16 & 18.69 & 23.79 & 6.53 & 11.63 & 12.00 & 15.30 & 9.23 & 12.90 & 17.27 \\
\hline $\mathrm{Na}_{2} \mathrm{O}$ & 0.19 & 0.09 & 0.14 & 0.08 & 0.05 & -0.01 & n.d. & 0.28 & 0.10 & 0.10 & 0.13 \\
\hline $\mathbf{K}_{2} \mathbf{O}$ & 1.07 & 0.89 & 0.86 & 0.81 & -0.03 & -0.08 & 1.50 & 0.70 & 1.03 & 1.26 & 0.32 \\
\hline $\mathbf{P}_{2} \mathbf{O}_{5}$ & 1.82 & 2.66 & 3.55 & 3.54 & 0.89 & 0.88 & n.d. & 1.83 & 0.97 & 0.40 & 0.81 \\
\hline $\mathrm{BaO}$ & 0.17 & 0.05 & 0.06 & 0.06 & 0.01 & 0.01 & n.d. & 0.01 & n.d. & n.d. & 0.16 \\
\hline $\mathbf{F}$ & & 0.15 & 0.19 & 0.17 & 0.04 & 0.02 & n.d. & n.d. & n.d. & n.d. & n.d. \\
\hline LOI & 9.20 & & & & 0.00 & 0.00 & & & & & \\
\hline $\mathrm{H}_{2} \mathrm{O}$ & & 2.48 & 3.18 & 1.76 & 0.70 & -0.72 & 12.30 & 6.20 & 8.72 & 9.07 & n.d. \\
\hline $\mathrm{CO}_{2}$ & & 7.36 & 9.82 & 12.71 & 2.46 & 5.35 & 7.00 & 4.77 & 5.13 & 9.88 & n.d. \\
\hline Sum & 98.5 & 100.0 & 100.0 & 100.0 & & & & & & & \\
\hline Mg\# & 85.7 & 85.8 & 83.5 & 83.2 & -2.26 & -2.56 & 86 & 82.5 & 86.9 & 86.9 & 80.1 \\
\hline
\end{tabular}

Table. 1: Measured and reconstructed whole-rock and primtive melt compositions. The following previous reconstructions of primitive kimberlite melts/magmas are shown for comparison: (1) Kimberley - Primary magma (le Roex et al. 2003); (2) Wesselton - Primitive melt (Shee 1985); (3) Lac de Gras - Low Ti Parental magma (Kjarsgaard et al. 2009); (4) Jerico - Primitive melt (before orthpyroxene assimilation - Kopylova et al. 2009); (5) Majuagaa - Parental melt (Nielson and Sand, 2008). †Total change represents the difference between reconstructed whole-rock value (i.e., Stage 1) and primtive melt (i.e., Stage 6).

Comparison between this primitive melt composition and experimentally produced low-degree melts of carbonated peridotite suggests the Bultfontein kimberlite could have been produced by $\sim 0.5 \%$ melting of a lherzolitic source at 6.0-8.6 GPa (i.e., $\sim 190-285 \mathrm{~km}$ ) and $1420-1500{ }^{\circ} \mathrm{C}$. The apparent lack 
of excess heat required for melt generation combined with the low-degree of melting is inconsistent with conventional views of plume-induced magmatism. Therefore, alternative processes of melt generation such as volatile flux melting or decompression melting should be considered.

Production of kimberlite melts by decompression melting of 'normal' shallow asthenospheric mantle is unlikely unless the source was previously enriched in $\mathrm{CO}_{2}, \mathrm{~K}_{2} \mathrm{O}, \mathrm{H}_{2} \mathrm{O}$, and $\mathrm{P}_{2} \mathrm{O}_{5}$ via metasomatism. This could be achived by long-term metasomatic redox pre-conditioning by carbonate-silicate melts (e.g., Yaxley et al. 2017). Alternatively, kimberlite melt generation may be triggered by volatile fluxing, when rising volatiles (i.e. fluids) interact with the source region (e.g., Bailey 1980; Tappe et al. 2013). These fluids would likely have high $\mathrm{CO}_{2} / \mathrm{H}_{2} \mathrm{O}$ ratios, and may also carry significant amounts of $\mathrm{K}_{2} \mathrm{O}, \mathrm{H}_{2} \mathrm{O}$ and $\mathrm{P}_{2} \mathrm{O}_{5}$.

\section{References}

Afanasyev A, Melnik O, Porritt L, Schumacher JC, Sparks, RSJ, (2014). Hydrothermal alteration of kimberlite by convective flows of external water. Contributions to Mineralogy and Petrology, 168 (1), 1-17.

Bailey DK, (1980). Volatile flux, geotherms, and the generation of the kimberlite-carbonatite-alkaline magma spectrum. Mineralogical Magazine, 43 (330), 695-699.

Giuliani A, Soltys A, Phillips D, Kamenetsky VS, Maas R, Goemann K, Woodhead JD, Drysdale RN, Griffin WL, (2016). The final stages of kimberlite petrogenesis: Petrography, mineral chemistry, melt inclusions and Sr-C-O isotope geochemistry of the Bultfontein kimberlite (Kimberley, South Africa). Chemical Geology.

Kamenetsky VS, Golovin AV, Maas R, Giuliani A, Kamenetsky MB, Weiss Y, (2014). Towards a new model for kimberlite petrogenesis: Evidence from unaltered kimberlites and mantle minerals. EarthScience Reviews, 139, 145-167.

Kjarsgaard BA, Pearson DG, Tappe S, Nowell GM, Dowall DP, (2009). Geochemistry of hypabyssal kimberlites from Lac de Gras, Canada: comparisons to a global database and applications to the parent magma problem. Lithos, 112, 236-248.

Kopylova MG, Matveev S, Raudsepp M, (2007). Searching for parental kimberlite melt. Geochimica et Cosmochimica Acta, 71 (14), 3616-3629.

le Roex AP, Bell DR, Davis P, (2003). Petrogenesis of Group I Kimberlites from Kimberley, South Africa: Evidence from Bulk-rock Geochemistry. Journal of Petrology, 44 (12), 2261-2286.

Nielsen TF, Sand KK, (2008). The Majuagaa kimberlite dike, Maniitsoq region, West Greenland: constraints on an Mg-rich silicocarbonatitic melt composition from groundmass mineralogy and bulk compositions. The Canadian Mineralogist, 46 (4), 1043-1061.

Sparks RSJ, Brooker RA, Field M, Kavanagh J, Schumacher JC, Walter MJ, White J, (2009). The nature of erupting kimberlite melts. Lithos, 112, 429-438.

Tappe S, Pearson DG, Kjarsgaard BA, Nowell G, Dowall D, (2013). Mantle transition zone input to kimberlite magmatism near a subduction zone: origin of anomalous $\mathrm{Nd}-\mathrm{Hf}$ isotope systematics at Lac de Gras, Canada. Earth and Planetary Science Letters, 371, 235-251.

Yaxley GM, Berry AJ, Rosenthal A, Woodland AB, Paterson D, (2017). Redox preconditioning deep cratonic lithosphere for kimberlite genesis-evidence from the central Slave Craton. Scientific reports, 7(1), 30. 